\title{
Den vanskelige journalen
}

\author{
«Litera scripta manet, verbum imbelle perit - det skrevne ord består, det talte forgår.» \\ Selv om det i våre dager er lett å produsere mengder av ord, kan alle ha nytte av noen \\ enkle råd om journalskriving, slik at produktet blir mer kvalitet enn kvantitet.
}

Tidligere måtte legen skrive journalen for hånd med kulepenn eller ved å klapre på en utslitt, hakkete skrivemaskin. I 1970årene var det mye generell kritikk mot journalskrivingen og et $\emptyset n s k e$ om at den måtte forbedres. Siden kom IT-eksplosjonen med datajournal i de vakreste fonter. Likevel gjøres det mange feil. Derfor er gode råd om journalskriving fra en generasjon tilbake fortsatt aktuelle - men på en ny måte.

Det er ikke helt lett å ta opp sykejournal. Ofte skjer det under vanskelige og dramatiske arbeidsforhold - pasienten er kritisk syk, det haster, mange andre pasienter venter, det er sent på natten, den stakkars legen er både sulten og trett... Dessuten har han eller hun ikke rukket å gå på toalettet på mange timer.

Hvordan pasientopplysningene skal samles og redigeres har vært et diskusjonsemne siden medisinens urtid. Selve journalopptaket består egentlig av tre hovedtemaer: Spørre ut pasienten, utføre en nøyaktig klinisk undersøkelse, komponere og skrive journalen (1). Bare undersøkelse av brystorganene var $\mathrm{i}$ tidligere tider emne for en hel bok (2) (den kom i åtte utgaver i årene 1886-1945), og Søren Bloch Laache (1854-1941), den sagnomsuste professor i indremedisin i Kristiania, forfattet en veileder i journalskriving for medisinstudentene (3). Den gikk studentene med på innerlommen. Og journalskriving var og er like viktig i allmennmedisinen som på det store sykehuset.

Forskrekket over alt han hadde sett av slette journaler skrev Nils Carl Lønberg (f. 1939) en artikkel i bladet Utposten i 1984. Han er oppvokst i Danmark. Med bakgrunn i den lune danske humoren og - ikke minst - mangeårig allmennpraksis i Norge gikk han i rette med kollegene. Det hører med til historien at han i sin tid var med på å ta initiativet til både det norske og det danske selskapet for medisinsk humor. Ellers taler artikkelen for seg selv.

Man kan spørre om ikke situasjonen er blitt bedre i de snart 30 årene som er gått siden den kom ut, for nå stirrer visstnok allmennlegen vel så mye inn i dataskjermen som på pasienten, og en elektronisk journal med de vakreste bokstaver kommer ut av printeren. Dessverre, så godt er det ikke. I tillegg til alle data som blir lagret elektronisk er papirflommen verre en noensinne. Undertiden kan det være vanskelig å finne ut av papirbunken hva som egentlig er selve journalnotatet. Derfor har vi enda større behov enn før for å gjenreise respekten for det skrevne ord. Da passer det å begynne med å lese Lønbergs artikkel på nytt.

\section{Ole Didrik Lærum}

ole.laerum@gades.uib.no

Ole Didrik Lærum (f. 1940) er professor (adj.) ved Finsenlaboratoriet/ Københavns Universitet og professor emeritus ved Gades institutt, Universitetet i Bergen

\section{Litteratur}

1. Braut GS, Gardsjord G, Perstølen E et al. red. Medisinsk journalskriving: rettleiing og journaldøme. 2. opplag. Bergen: Medisinsk mållag, 1987.

2. Liisberg J. Vejledning i undersøgelse af brystorganerne. En lærebog for studerende. 6. utg. København: Andr. Fred. Høst \& søns forlag, 1931

3. Laache S. Momenter til udarbeidelse af medicinske sygejournaler: med angivelse af en del symptomatologiske holdepunkter til brug for medicinske studerende. Kristiania: Steen'ske bogtrykkeri og forlag, 1905.

\section{Journalføring i almenpraksis - et tema med mange variasjoner}

Nils Lønberg. Utposten 1984; 13: 37-9.

Pasientjournaler i almenpraksis forteller ofte lite om pasientene - men mye om legene.

Journalene burde vise pasientenes symptomer, legens observasjoner, overveielser og handlinger, samt resultatet av videre undersøkelser.

Journalføring i almenpraksis er ikke standardisert og journalenes kvalitet varierer sterkt. Regelmessig ser man journaler i form av en svær papirhaug sammensatt av følgende hovedingredienser:
1. Et enormt antall gamle prøvesvar, urindyrkninger, cytologier etc.

2. Et antall epikriser i tilfeldig orden.

3. Ett eller flere ark med håndskrevne notater, mer eller mindre leselig.

\section{Den vanligste feil i journalføringen}

Uleselighet (archivitis cryptica) (Fig. 1 og 2) Over halvparten av norske leger skriver fortsatt journalen for hånd. I tillegg til dårlig leselighet er det en klar tendens blant håndskrivende leger til å skrive insuffisiente journaler.
Insuffisiente notater og stikkordsnotater (archivitis parva) (Fig. 3 og 4)

Det er fristende å innhente forsinkelsene $i$ det daglige arbeidet ved å klore ned noen få ord om pasienten som nettopp gikk ut av døren, men det kan hevne seg neste gang pasienter kommer, kanskje før.

\section{Overdrevne notater}

(dictafonitis chronica) (Fig. 5)

Leger som dikterer sine journaler er tilsynelatende underkastet en naturlov som gjør nota- 
tene 2-5 ganger så lange som hvis de selv hadde skrevet. Notatets innhold og budskap pakkes inn i store mengder «ordsalat», og notatene må leses flere ganger for å oppfattes.

Cerumenskylling formuleres som om det skulle være en større operasjon og notatet avsluttes ofte med intetsigende bemerkninger som «ringer igjen hvis ikke bedre» eller «kontroll hos distriktslegen i neste uke».

Rotete journaler (desorientatio verticalis) Journaler med 20-30 foreldede prøvesvar er ganske vanlig i almenpraksis. Åpenbart er det en tilbøyelighet til å anse alle bilag for dokumenter av stor betydning - eller er det den «dårlige tid» som igjen skal brukes som unnskyldning?

\section{Akronologisk journalføring (archivitis maligna saltans)}

I noen journaler blir notatene ført på forskjellige ark simpelthen fordi noen ark har skjult seg mellom gamle cytologier og urindyrkninger. Journalen fremkommer derfor på to eller flere ark. Det finnes journaler hvor sykebesøk blir diktert og skrevet på små lapper som stikkes inn i journalen og dermed inngår i haugen av små bilag, men senere vil mangle i oversikten.

\section{Manglende sykehistorie}

(agenesia anamnestica)

Svært få leger har en oversiktlig sykehistorie over sine pasienter. De fleste støtter seg til epikrisene som ofte resymerer hovedpunktene, men når mange sykehistorier forutsetter sykehistorien kjent, er man like langt.

\section{Manglende sosialanamnese}

(foramen magnum socialis)

En rimelig kortfattet oversikt over pasientens arbeidsforhold, familieforhold og boligforhold mangler i nesten alle journaler. Et rimelig kjennskap til pasienten har man først når man er noenlunde klar over hvilke forhold vedkommende har i hjem og på arbeidsplassen.

\section{Hva er årsaken til disse feilene?}

Det er ingen veiledning, ingen standard, ingen kontroll.

Den fastgrodde, men feilaktige oppfatning at maskinskriving er urealistisk for:

- min håndskrift er jo bra nok

- jeg kan ikke skrive på maskin

- jeg har ikke råd til skrivehjelp

Mangel på oversiktsark.

Manglende sans for bilagenes relevans.

Mangel på tid (virkelig og innbilt).

Sykehusjournaler er av flere grunner dårlig egnet som forbilde for journalføring i almenpraksis. Anamnese, objektiv undersøkelse og konklusjoner vedrører som regel noen ganske få problemer og symptomer.



Fig. 1: Uleselig journal.

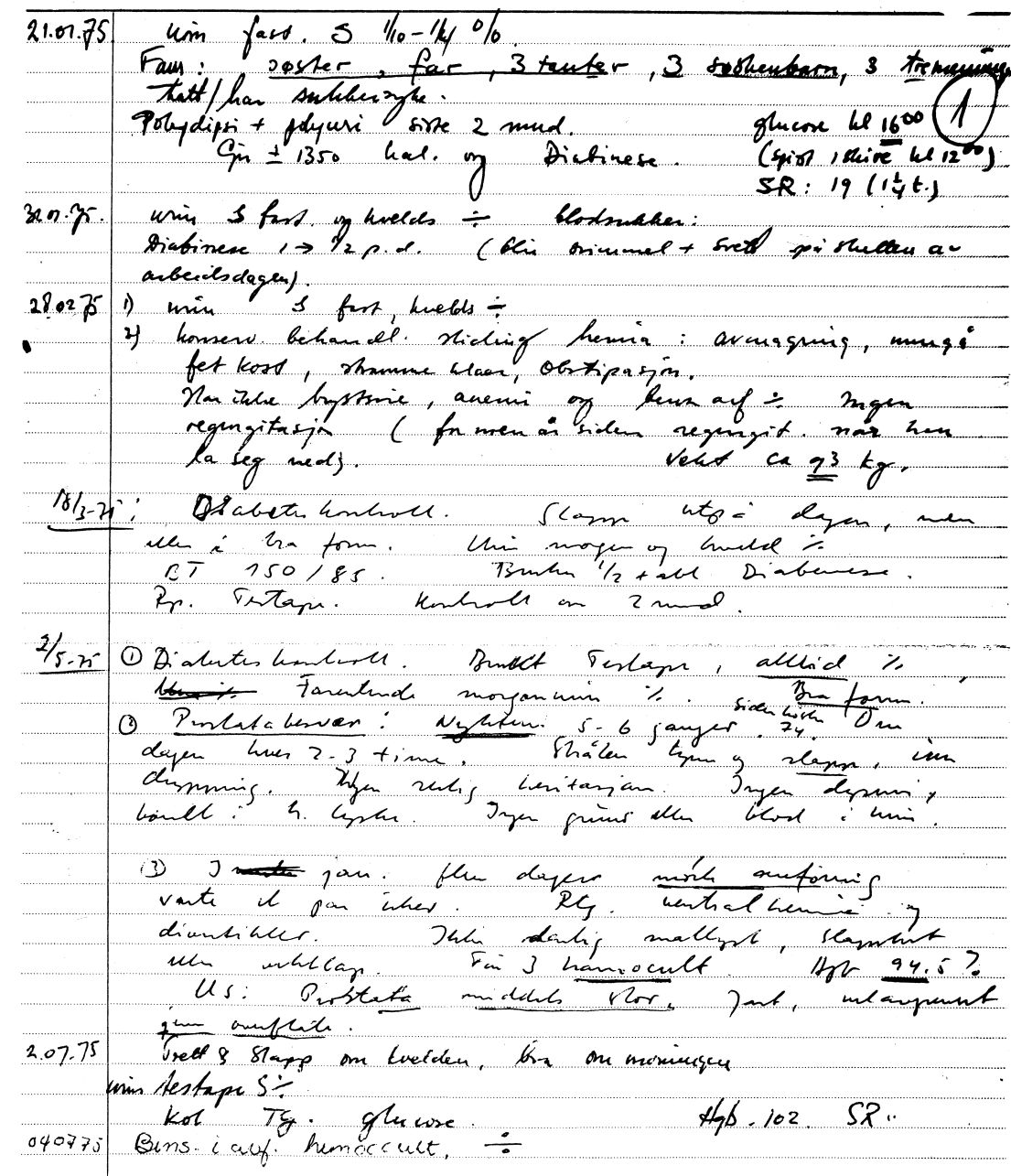

Fig. 2: Uleselig journal. 
15/8-67: Hun hor hatt on del plaser med svirmelhet on rorsenen. Otoscopi: N Ikke sekresjon frs esex. Lett rubor i fauces. Hab: Rp Valiur 1Uns, 100, $\frac{\dot{t}}{2}-1 \times 2$.

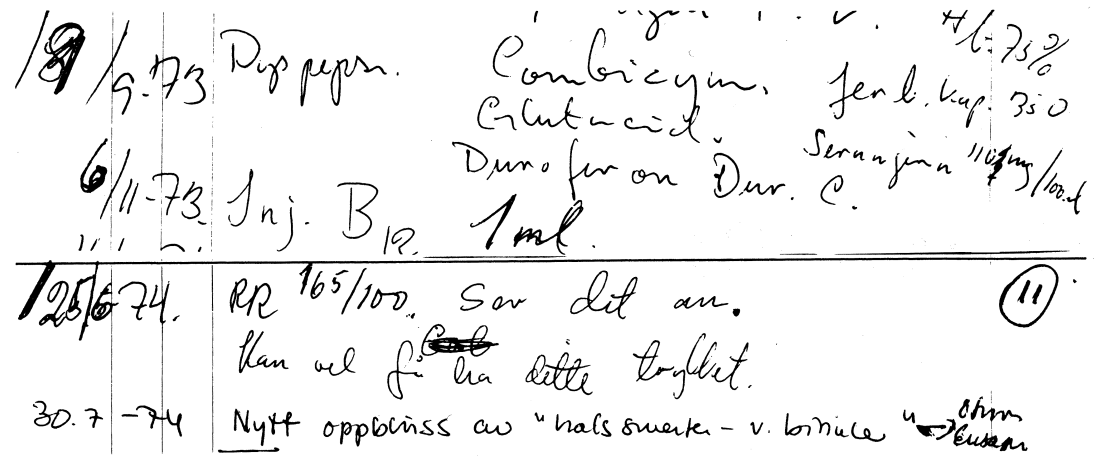

Fig. 4: Insufficient journal.

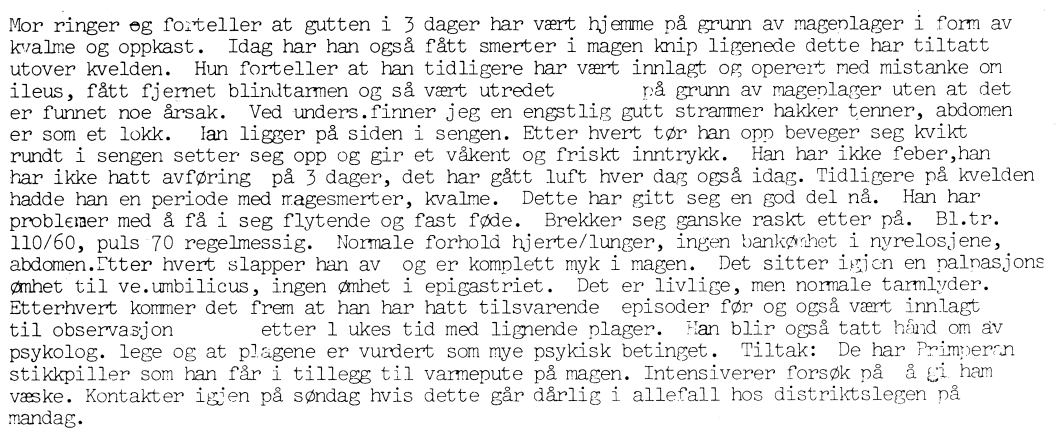

Fig. 5: Diktafonitis.

Dessuten er det en alminnelig uvane på mange sykehusavdelinger at journalene ikke ajourføres etterhvert, men at man gjør små notater på kurvene. Etter pasientens utskrivelse komponeres et utskrivingsnotat preget av en oppramsing av et stort antall blodprøver krydret med en sykdomsbeskrivelse av varierende kvalitet. Til slutt finnes passende diagnostiske etiketter frem og hvis ingen passer kan man forsøke «observatio», «psykoneurosis» eller «funksjonelle plager».

Primærlegetjenesten er et avgjørende ledd $i$ helsetjenesten og alvorlige og sjeldne sykdommer vurderes som regel først av primærlegen. Overføringen av pasientens plager til papiret er ikke underkastet særlige regler uten noen få paragrafer som få kjenner til og ingen bryr seg om. Journalen blir derfor et uttrykk for legens høyst personlige smak og forgodtbefinnende. Et par håndskrevne ord som i høyden kan støtte hans egen hukommelse $i$ kort tid er til liten hjelp for ham selv etter lenger tid, og slett ikke til støtte for hans kollega.

\section{Krav til journalføringen}

Med stigende krav til kvaliteten av legens arbeid vil det være naturlig å formulere noen minstekrav til journalføringen.
Kravene til en god almenmedisinsk journal kunne være:

1. Den må være leselig, dvs. maskinskrevet.

2. Den må være fullstendig («uten huller»).

3. Den må være kronologisk.

4. Notatene må være suffisiente og oversiktlige uten overflødige floskler.

5. Journalen må omfatte oversikt over pasientens sykehistorie.

6. Journalen må opplyse om pasientens viktigste sosiale forhold.

7. Journalen må være ajourført og ordnet.

Blant grunnene for å standardisere journalføringen kan nevnes:

- Kunnskapen om pasienten og symptomene er vår viktigste kilde til viten. Notater om pasientens klager og våre objektive funn er vårt «råmateriale» til diagnostikk, behandling og forskning.

- Pasienter i primærhelsetjenesten har ofte mangfoldige klager og diffuse sykdommer. Hovedklagen dukker undertiden først opp etter flere konsultasjoner og utviklingen av symptomer er av største betydning.

- I samarbeidet mellom flere primærleger er en enhetlig journalføring en nødvendighet. Kolleger kan umiddelbart overta pasienten, problemene og utredningen.

- De rettsmedisinske aspekter bør man ha i tankene selv om rettsmedisinske krav til

\section{$\square$ Av Nils Lønberg}

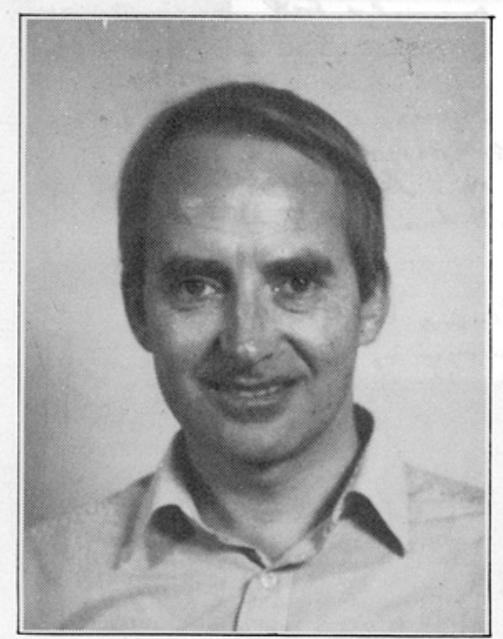

NILS LøNBERG har en fot i Danmark og en i Norge. Han har dansk temperament og aksent. Hovedinteresser: journalføring, opera og manuell medisin. Yndlingsaversjoner: ordsalat, lutefisk og polyfarmasi. Svakheter: Snakker for mye og skriver for lite. Han er distriktslege i Sandøy kommune, Møre og Romsdal fra 1981. Sist år brukte han et almenpraktikerstipend til å gjøre en undersøkelse over legejournaler i primærhelset jenesten.

journalføring spiller en beskjeden rolle i de fleste legers bevissthet. Selv i Skandinavia har leger blitt dømt for forhold der mangelfull journalføring har vært avgjørende (hovedsaklig saker om medisinmisbruk).

Den problemorienterte journal som introdusert av Weed har stimulert interessen for journalføring og prinsippene er av flere forfattere søkt tilpasset forholdene i almenpraksis.

\section{Konklusjon}

Kvaliteten av legens arbeid avhenger av mange forhold. Bl.a. legens erfaring, viten og kunnen, den tid han bruker på pasienten, kollegialt samarbeid og samarbeid med sykehus.

Journalene kan være til stor hjelp når man skal lære av symptomer og problemer. Dette betyr at man av og til må stille seg spørsmålene

- Hva glemte du å spørre om?

- Hva glemte du å undersøke?

- Hva unnlot du å gjøre?

- Hva gjorde du feil?

Disse spørsmålene kan kun besvares dersom journalføringen er av en anstendig kvalitet. 